[Reprinted from Inorganic Chemistry, 12, 2730 (1973).]

Copyright 1973 by the American Chemical Society and reprinted by permission of the copyright owner.

Contribution from the Department of Physic University of Nijmegen, Nijmegen, The Neth

\title{
Iron(II) Complexes with Two and Three Dialkyldithiocarbamate Ligands. Mossbauer and Electronic Spectra
}

\author{
J. L. K. F. de VRIES, J. M. TROOSTER, and E. de BOER*
}

Received February 5, 1973

\begin{abstract}
A series of tris( $N, N$-dialkyldithiocarbamato)iron(II) complexes has been synthesized for the first time. The Mossbauer and electronic spectra of these complexes together with those of bis( $N, N$-dialkyldithiocarbamato)iron(II) have been measured. Small isomer shift values confirm the covalent character of the iron-sulfur bonds. The quadrupole splitting differs for sixand five-coordination; both coordination numbers occur in the bis(dimethyldithiocarbamato)iron(II) complex.
\end{abstract}

\section{Introduction}

$\operatorname{Tris}(N, N$-dialkyldithiocarbamato)iron(III) complexes ( $\mathrm{Fe}$ $\left(\mathrm{R}_{2} \mathrm{dtc}\right)_{3}$ ) have been investigated thoroughly with the help of Mossbauer spectroscopy and other techniques. ${ }^{1-5}$ Recently the iron(IV) analog $\left(\mathrm{BF}_{4}\right) \mathrm{Fe}\left(\mathrm{R}_{2} \mathrm{dtc}\right)_{3}$ was prepared by Pasek and Straub. ${ }^{6}$ Pignolet, Lewis, and Holm have reported the synthesis of $\mathrm{Fe}\left(\mathrm{R}_{2} \mathrm{dtc}\right)_{2} \mathrm{tdf}^{7}$ and $\mathrm{Fe}\left(\mathbf{R}_{2} \mathrm{dtc}\right)_{2} \mathrm{mnt}^{8}$ where $\mathrm{tdf}=$ perfluoromethyldithiolene and $\mathrm{mnt}=$ maleonitriledithiolene. These complexes contain similarly a $\mathrm{FeS}_{6}$ core. A review on this type of compound was given by Coucouvanis. ${ }^{9}$ In this work the preparation and properties of the corresponding iron(II) complexes $\left(\mathrm{R}_{4}{ }_{4} \mathrm{~N}\right) \mathrm{Fe}\left(\mathrm{Et}_{2} \mathrm{dtc}\right)_{3}\left(\mathrm{R}_{4}{ }_{4} \mathrm{~N}^{+}\right.$is a tetraalkylammonium ion) are discussed in connection with measurements on $\mathrm{Fe}\left(\mathrm{R}_{2} \mathrm{dtc}\right)_{2}$ complexes. ${ }^{7,10,11}$ These iron(II) complexes were investigated mainly by means of Mossbauer spectroscopy and electronic spectroscopy. Because of the air sensitivity of the compounds these techniques offer advantages over other experimental procedures.

\section{Experimental Section}

Preparation of the Complexes. The complexes discussed in this paper are very air sensitive, even when dry; hence all preparations were carried out under exclusion of air using vacuum techniques.

The bis( $N, N$-dialkyldithiocarbamato)iron(II) complexes $\left(\mathrm{Fe}\left(\mathrm{R}_{2}\right.\right.$ -

(1) A. H. White, E. Kokot, H. Waterman, and R. L. Martin, Aust. J. Chem., 17, 294 (1964).

(2) A. H. Ewald, R. L. Martin, I. G. Ross, and A. H. White, Proc. Roy. Soc., Ser. A, 280, 235 (1964).

(3) R. Rickards, C. E. Johnson, and H. A. O. Hill, J. Chem. Phys., 48, 5231 (1968).

(4) R. L. Martin and A. H. White, Transition Metal Chem., 4, 113 (1968) (general review).

(5) L. M. Epstein and D. K. Straub, Inorg. Chem., 8, 784 (1969).

(6) E. A. Pasek and D. K. Straub, Inong. Chem., i1, 259 (1972).

(7) L. H. Pignolet, R. A. Lewis, and R. H. Holm, J. Amer. Chem. Soc., 93, 360 (1971).

(8) L. H. Pignolet, R. A. Lewis, and R. H. Holm, Inorg. Chem., dtc) ${ }_{2}$ with $\mathrm{R}=$ methyl, ethyl, $n$-propyl, $n$-butyl, or pheny pared by mixing aqueous solutions of stoichiometric amo rous sulfate and the sodium salt of the dithiocarbamate It The ligand solution may also be prepared by adding $\mathrm{CS}_{2}$ stirred solution of $\mathrm{NaOH}$ and the appropriate dialkylamin phenylamine. The sulfate and ligand solutions were thor gassed by a repeated freezing, pumping, and thawing proc ter mixing both solutions the suspension of the complex ed on a filter and flushed with previously degassed water. ing water was collected for later analysis and the complex by immersing part of the apparatus in liquid nitrogen.

The iron(II) tris(dithiocarbamate) complexes ( $\mathrm{Fe}\left(\mathrm{Et}_{2}\right.$ prepared in the same way, but now an excess of tetraalky um chloride $\left(\mathbf{R}^{\prime} \mathrm{NCl}, \mathbf{R}^{\prime}=\right.$ butyl or ethyl) or tetraphenyl chloride $\left(\mathrm{Ph}_{4} \mathrm{PCl}\right)$ was added to the ferrous sulfate solutic purification of the tris complexes has to take place withir time, otherwise $\mathrm{Fe}\left(\mathrm{Et}_{2} \mathrm{dtc}\right)_{2}$ is formed. This can be obse change of color from brightly yellow to brown. In the $f$ the presence of $\mathrm{Fe}\left(\mathrm{Et}_{2} \mathrm{dtc}\right)_{2}$ is easily revealed by its Moss trum. On adding dithiocarbamate ligand to the reaction the tris complex can be formed again from the bis compl stability of the tris complexes decreases with decreasing $s$ cation: $\left(\mathrm{Et}_{4} \mathrm{~N}\right) \mathrm{Fe}\left(\mathrm{Et}_{2} \mathrm{dtc}\right)_{3}$ transforms easily into the bis and attempts to prepare $\mathrm{NaFe}\left(\mathrm{Et}_{2} \mathrm{dtc}\right)_{3}$ were unsuccessfu evidence was found for the formation of $\mathrm{Fe}\left(\mathrm{Et}_{2} \mathrm{dtc}\right)_{2} \mathrm{Cl}^{-}$: Mossbauer spectra of complexes prepared with an excess $\mathrm{Bu}_{4} \mathrm{NBr}$, and $\mathrm{Bu}_{4} \mathrm{NI}$ are identical, (b) the complex could : pared with the use of $\left(\mathrm{Bu}_{4} \mathrm{~N}\right)_{2} \mathrm{SO}_{4}$, (c) no $\mathrm{Et}_{2} \mathrm{dtc}^{-}$has bee the washing water if stoichiometric amounts of starting $\mathrm{m}$ were used, and (d) no halogen was found in the complex iron-chlorine band was observed in the infrared spectrum ucts have been characterized by ir, Mossbauer, and electrs and by elemental analyses. Since elemental analyses cou carried out in the presence of air, oxidation could not be

Anal. Calcd for $\mathrm{Fe}\left(\mathrm{Me}_{2} \mathrm{dtc}\right)_{2}$ : C, 24.32; H, 4.09; N, Found: C, 23.93; H, 3.96; N, 9.29. Calcd for $F e\left(E t_{2} \mathrm{dt}_{\mathrm{t}}\right.$ $34.06 ; \mathrm{H}, 5.71 ; \mathrm{N}, 7.94$. Found: $\mathrm{C}, 33.67 ; \mathrm{H}, 5.81 ; \mathrm{N}$, for $\mathrm{Fe}\left(\mathrm{Ph}_{2} \mathrm{dtc}\right)_{2}$ : C, 57.33; H, 3.69; N, 5.13. Found: ' $3.85 ; \mathrm{N}, 4.81$. (The agreement is further improved by $\mathrm{cc}$ experimental values with the percentages calculated for $a$ products $\left[\mathrm{Fe}\left(\mathrm{R}_{2} \mathrm{dtc}\right)_{2}\right]_{2} \mathrm{O}$. Calcd for $\mathrm{R}=\mathrm{Me}: \mathrm{C}, 23.68$ 
$\left(\mathrm{Et}_{2} \mathrm{dtc}\right)_{3}$ : C, 55.76; H, 6.00; N, 5.00. Found: C, 53.44; H, 5.78; $\mathrm{N}, 4.93$. It is seen that the ratios between the percentages calculated for the iron(II) complex and the values found for the complex after exposure to air are 1.04 on the average for all three elements The nature of the oxidation products formed and thus the amount of oxygen taken up is not known yet; the process may be rather complicated as was also observed in the formation of iron(IV) dithiocarbamates from iron(III) dithiocarbamates. ${ }^{6}$ The iron:ligand ratio was checked by using stoichiometric amounts of starting materials and analyzing the washing water; no ferrous ions or ligand could be detected. The $\mathrm{C}, \mathrm{H}$, and $\mathrm{N}$ analyses were carried out on samples whose Mossbauer spectra confirmed the presence of only one species. No analyses were made of $\mathrm{Fe}\left(n-\mathrm{Pr}_{2} \mathrm{dtc}\right)_{2}$ and $\mathrm{Fe}\left(n-\mathrm{Bu}_{2} \mathrm{dtc}\right)_{2}$, since the close agreement of the Mossbauer parameters with those of $\mathrm{Fe}$ $\left(\mathrm{Et}_{2} \mathrm{dtc}\right)_{2}$ as well as the ir data leave no doubt with regard to the formation of these complexes.

Mossbauer and Optical Measurements. Mossbauer spectra were recorded with a constant-acceleration spectrometer using an electromechanical transducer and a multichannel analyzer in the time mode. The velocity scale was calibrated using an iron-foil spectrum. For the low-temperature spectra the absorbers were mounted on a copper tube immersed in liquid nitrogen and thermally isolated with Styrofoam. With a heater the temperature could be regulated to within $1^{\circ}$. Absorbers were prepared in the glove box (VAC HE-43-6), where the powders were sealed in polypropylene capsules ${ }^{12}$ and thus were protected from air. As the Mossbauer source ${ }^{57} \mathrm{Co}$ in palladium was used. The accuracy of the Mossbauer data is $0.03 \mathrm{~mm} / \mathrm{sec}$, unless stated otherwise. The electronic absorption spectra of the complexes were measured in the solid state with a Cary 14 spectrometer. Solid-state spectra were preferred since on dissolving the complexes unexpected reactions may occur. Absorbers were prepared in the glove box by mixing the complex with $\mathrm{KBr}$; the mixture was placed in a die, enclosed in a plastic bag, and taken out of the box. In this way pellets could be pressed in the absence of air. Once pressed, the samples were found to be insensitive to air.

\section{Results and Discussion}

a. Reaction Mechanisms. The reversible conversion in water of the tris(dithiocarbamate) complexes into the bis complexes suggests the following equilibria in the absence of oxygen

$$
\begin{aligned}
& \left(\mathrm{R}^{\prime}{ }_{4} \mathrm{~N}\right) \mathrm{Fe}\left(\mathrm{Et}_{2} \mathrm{dtc}\right)_{3} \frac{\mathrm{H}_{2} \mathrm{O}}{{\text { excess } \mathrm{R}^{\prime}{ }_{4} \mathrm{~N}^{+}}^{*}} \mathrm{Fe}\left(\mathrm{Et}_{2} \mathrm{dtc}\right)_{3}{ }^{-}+\mathrm{R}^{\prime}{ }_{4} \mathrm{~N}^{+} \frac{\mathrm{H}, \mathrm{O}}{\text { excess } \mathrm{Et}{ }_{2} \mathrm{dtc}^{-}} \\
& \mathrm{Fe}\left(\mathrm{Et}_{2} \mathrm{dtc}\right)_{2}+\mathrm{Et}_{2} \mathrm{dtc}^{-}+\mathrm{R}_{4}^{\prime} \mathrm{N}^{+}
\end{aligned}
$$

In agreement with this proposed equilibrium the oxidation products of $\left(\mathrm{R}_{4}^{\prime} \mathrm{N}\right) \mathrm{Fe}\left(\mathrm{Et}_{2} \mathrm{dtc}\right)_{3}$ differ for wet oxidation and dry oxidation. The Mossbauer spectrum of the oxidation product obtained in the presence of water resembles that of the oxidation product of $\mathrm{Fe}\left(\mathrm{Et}_{2} \mathrm{dtc}\right)_{2}$. When $\mathrm{Fe}\left(\mathrm{Et}_{2} \mathrm{dtc}\right)_{3}{ }^{-}$ complexes are oxidized in the absence of water, various observations indicate that $\mathrm{Fe}\left(\mathrm{Et}_{2} \mathrm{dtc}\right)_{3}$ is formed: (a) on washing the oxidation product, no ligand was found in the washing water; (b) Mossbauer spectra (see Table II) and infrared spectra were identical with those of $\mathrm{Fe}\left(\mathrm{Et}_{2} \mathrm{dtc}\right)_{3}$, including the characteristic QS dependence on the temperature; ${ }^{5}$ (c) finally the electronic spectrum of the oxidation product was the same as the spectrum of $\mathrm{Fe}\left(\mathrm{Et}_{2} \mathrm{dtc}\right)_{3}$, showing one spin-forbidden band at $6500 \mathrm{~cm}^{-1}$ (see Figure $4 \mathrm{~b}$ and $4 \mathrm{c}$ ).

It is interesting to compare these oxidation reactions with the oxidation process of $\mathrm{Fe}\left(\mathrm{R}_{2} \mathrm{dtc}\right)_{2}$, which in water is oxidized slowly. If this oxidation product $(\mathrm{QS}=1.28 \mathrm{~mm} / \mathrm{sec}$; see Table II) is recrystallized from chloroform, the QS of the compound is reduced to $0.59 \mathrm{~mm} / \mathrm{sec}$. A possible explanation is that in the first oxidation product the dimers occurring in the iron(II) complex are still present, while on recrystallization the dimers dissociate and a complex with the same elemental composition but with different geometry is formed.
Table I. Mossbauer Parameters (mm/sec) of Iron(II) Dithiocarbamate, Xanthate (xn), and Diselenocarbama: Complexes, Measured at $100^{\circ} \mathrm{K}^{a}$

\begin{tabular}{lccll}
\hline & IS & QS & & \\
\hline $\mathrm{Fe}\left(\mathrm{Me}_{2} \mathrm{dtc}\right)_{2}$ & 1.19 & 4.10 & $\mathrm{Fe}\left(n-\mathrm{Bu}_{2} \mathrm{dtc}\right)_{2}$ & 1. \\
& 1.22 & 2.53 & $\mathrm{Fe}\left(\mathrm{Ph}_{2} \mathrm{dtc}\right)_{2}$ & 1. \\
$\mathrm{Fe}\left(\mathrm{Et}_{2} \mathrm{dtc}\right)_{2}{ }^{b}$ & 1.16 & 4.16 & $\mathrm{Fe}(n-\mathrm{Bu}(\mathrm{xn}))_{2}$ & 1. \\
$\mathrm{Fe}\left(n-\mathrm{Pr}_{2} \mathrm{dtc}\right)_{2}$. & 1.14 & 4.15 & $\mathrm{Fe}\left(\mathrm{Et}_{2} \mathrm{dsc}\right)_{2}$ & 1.
\end{tabular}

$a$ IS is given relative to $\mathrm{Na}_{2} \mathrm{Fe}(\mathrm{CN})_{5} \mathrm{NO}-2 \mathrm{H}_{2} \mathrm{O}$. b See

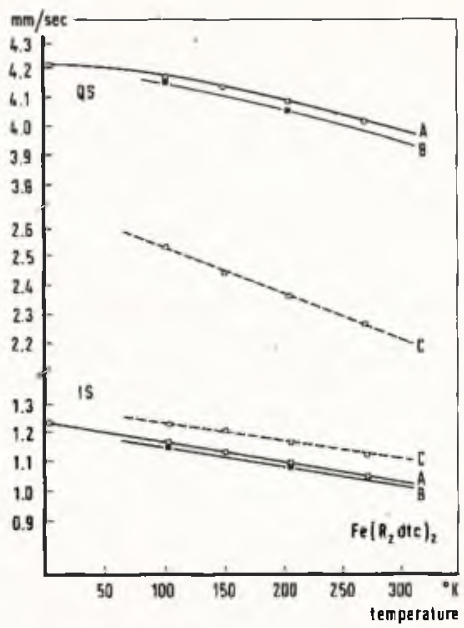

Figure 1. IS and QS as functions of temperature for ( $(\mathrm{Et}, \mathrm{dtc})_{2},(\mathrm{~B}) \mathrm{Fe}\left(n-\mathrm{Pr}_{2} \mathrm{dtc}\right)_{2}$, and (C) the extra site of $]$

spectra were measured on bis(dithiocarbamate) with five different $\mathbf{R}$ groups. The results are pr Table I. In Figure 1 the temperature dependen Mossbauer parameters of three species is shown powder spectra have shown that the $\mathrm{Fe}\left(\mathrm{Et}_{2} \mathrm{dtc}\right)$ curs in the dimeric form, the iron atom being $\mathrm{cr}$ five sulfur atoms. ${ }^{11}$ The spin multiplicity has 1 measured. In a recent paper ${ }^{13}$ it was shown by orbital calculations that the quadrupole splittin ed for the high-spin configuration $(S=2)$ is in $r$ agreement with the experimental QS than the $C$ lated for the intermediate spin state $(S=1)$. T dination was shown to result in four relatively , energy levels with mainly iron $3 \mathrm{~d}$ character; the energy differences between these levels are of $t$ ? $1000 \mathrm{~cm}^{-1}$. A fifth level with mainly $3 \mathrm{~d}_{x y}$ cha ing toward the sulfur atoms) lies much higher ( $\mathrm{cm}^{-1}$ ). Nevertheless this level contributes sign the QS since due to covalency the $3 \mathrm{~d}_{x y}$ atomic tion is considerably larger than 1.00 (see ref 13 Thus the unusually large $\mathrm{QS}$ arises from the con five-coordination and strong covalency of the ir bonds. The observed temperature dependence suggests the spacing between the lowest levels n acter to be a few hundred reciprocal centimeter instead of the calculated $1000 \mathrm{~cm}^{-1}$

The values of the isomer shifts (IS) are somew than for most other high-spin iron(II) compoun the IS is on the average $1.4 \mathrm{~mm} / \mathrm{sec}$. This can $?$ to the considerable degree of covalency in the $i$ bonds and to the five-coordination. ${ }^{11}$ The six-1 iron(II) tris(dithiocarbamates) have a slightly hi temperature dependence of the IS's of the iront 
the second-order Doppler shift. For complexes with $\mathrm{R}=$ e thyl and $n$-propyl no d-d transitions in the electronic spectrum were observed, in spite of the low symmetry and in contrast with the five-coordinated iron(III) complex $\mathrm{Fe}\left(\mathrm{Et}_{2} \mathrm{dtc}\right)_{2} \mathrm{Cl}^{13}$ Occasionally samples of $\mathrm{Fe}\left(\mathrm{Me}_{2} \mathrm{dtc}\right)_{2}$ exhibited two broad, weak absorption bands in the near-infrared-visible region, viz., at 6600 and $9400 \mathrm{~cm}^{-1}$. These bands, which disappear on oxidation, are probably $\mathrm{d}-\mathrm{d}$ bands corresponding with ${ }^{5} \mathrm{E}_{\mathrm{g}} \leftarrow{ }^{5} \mathrm{~T}_{2 \mathrm{~g}}$ transitions; the corresponding $10 D q$ value is about $8000 \mathrm{~cm}^{-1}$. The Mossbauer spectra of samples showing these electronic transitions invariably show the presence of a second quadrupole pair; see Figure 2. The relative intensity of the two Mossbauer quadrupole pairs varied with each preparation and no systematic dependence on the preparation procedure was found. Formation of $\mathrm{Fe}\left(\mathrm{Me}_{2} \mathrm{dtc}\right)_{2}$ $\left(\mathrm{H}_{2} \mathrm{O}\right)_{2}$ is not likely on the basis of elemental analyses, which gave results as reported in the Experimental Section independent of the ratio of the two quadrupole pairs. Furthermore, heating under vacuum did not change the relative intensity of both pairs, the infrared spectra did not show any peaks that could be ascribed to monodentate dithiocarbamate ligand ${ }^{14}$ or to thiuram disulfide, and the electronic spectrum is very similar to that observed for $\mathrm{Fe}\left(\mathrm{R}_{\mathbf{2}} \mathrm{dtc}\right)_{3}{ }^{-}$, where iron is sixcoordinated (see next section). These observations lead us to conclude that partly reaction to six-coordination has taken place, in agreement with the smaller $\mathrm{QS}$, which is in the range of QS values normally observed for neutral high-spin six-coordinated iron(II) chelates. It is reasonable to assume that six-coordination in the dithiocarbamate complex occurs by polymerization between two or more dimeric units. In highspin iron(II) chelates with ligands binding through oxygen or nitrogen, polymerization is very common. ${ }^{15}$ Coordination by six sulfur atoms similar to that proposed here for the second configuration of $\mathrm{Fe}\left(\mathrm{Me}_{2} \mathrm{dtc}\right)_{2}$ has been observed recently for $\mathrm{Cu}$ (II) in $\mathrm{Cu}^{\mathrm{II}}\left(\mathrm{Bu}_{2} \mathrm{dtc}\right)_{2} \cdot 2 \mathrm{Cu} \mathrm{CI}\left(\mathrm{Bu}_{2} \mathrm{dtc}\right)_{2} \mathrm{Cd}_{2} \mathrm{Br}_{6} \cdot{ }^{16}$ It is interesting to note that the QS and IS measured on the related iron(II) bis( $n$-butyl xanthate) complex, listed in Table I, also suggest six-coordination in this compound. The larger QS indicating five-coordination has never been observed in this case.

The effect of covalency of the iron-ligand bond can be investigated by replacing the sulfur atoms by selenium. Preliminary results on iron(II) bis(diselenocarbamate) (prepared from ${ }^{57} \mathrm{FeCl}_{2}$ and zinc(II) bis(diselenocarbamate) gave QS = $4.06 \mathrm{~mm} / \mathrm{sec}$ and IS $=1.09 \mathrm{~mm} / \mathrm{sec}$. The large QS points to five-coordinated iron in this complex; the low IS indicates that the iron-selenium bond is even more covalent than an iron-sulfur bond.

c. Iron(II) Tris(dithiocarbamate) Complexes. In Table II the Mossbauer data of tris(dithiocarbamate) complexes are listed and in Figure 3 some Mossbauer spectra are shown. The IS's are indicative of high-spin complexes, and the temperature dependence of the IS's indicates the absence of spinstate equilibria in contrast with the corresponding $\mathrm{Fe}\left(\mathrm{Et}_{2} \mathrm{dtc}_{3}\right.$ complexes. $^{2,5}$ Apparently in the less covalent iron(II) compounds the low-spin state is energetically unfavorable. The QS's are normal for six-coordinated high-spin iron(II). There is no relationship between QS and the size of the counterion. In the isoelectronic $\mathrm{NiN}\left(\mathrm{Et}_{2} \mathrm{dtc}\right)_{3}{ }^{+}$complex the metal site

(14) A. Domenicano, A. Vaciago, L. Zambonelli, P. L. Loader, and L. M. Venanzi, J. Chem. Soc. D, 476 (1966); C. O'Conner, J. D.

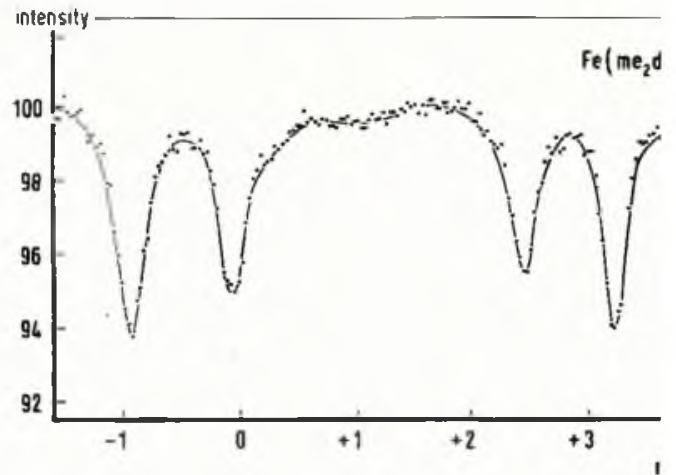

Figure 2. Mossbauer spectrum of $\mathrm{Fe}\left(\mathrm{Me}_{2} \mathrm{dtc}\right)_{2}$ showing ti sites (see text), measured at $100^{\circ} \mathrm{K}$.

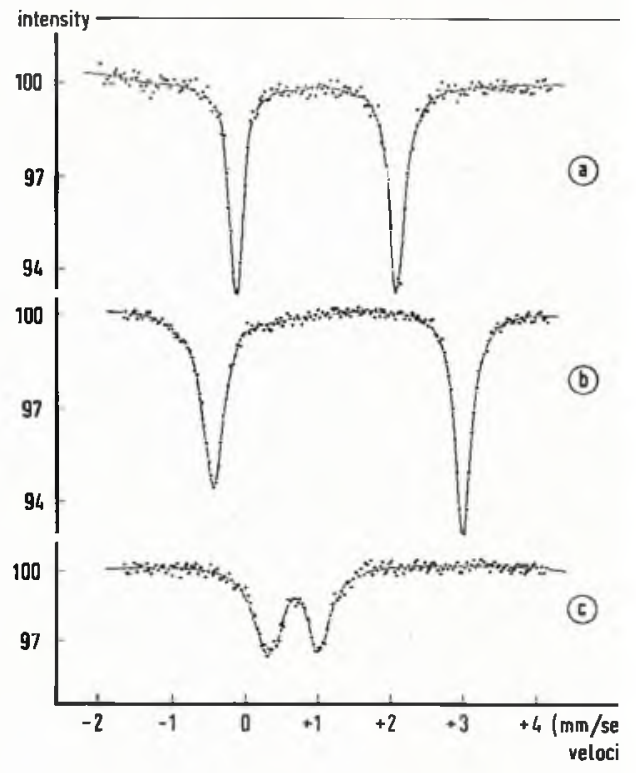

Figure 3. Mossbauer spectra of (a) $\left(\mathrm{Ph}_{4} \mathrm{P}\right) \mathrm{Fe}\left(\mathrm{Et}_{2} \mathrm{dtc}\right)_{3},(\mathrm{t}$ $\mathrm{Fe}\left(\mathrm{Et}_{2} \mathrm{dtc}\right)_{3}$, and (c) $\left(\mathrm{Bu}_{4} \mathrm{~N}\right) \mathrm{Fe}\left(\mathrm{Et}_{2} \mathrm{dtc}\right)_{3}$ after oxidation, at $100^{\circ} \mathrm{K}$.

Table II. Mossbauer Parameters of Some Fe(Et $\mathrm{dtc}_{2}{ }_{3}{ }^{-} \mathrm{C}$ and of Oxidation Products of Iron(II) Dithiocarbamates (

\begin{tabular}{|c|c|c|c|}
\hline & \multicolumn{2}{|c|}{$100^{\circ} \mathrm{K}$} & \multirow{2}{*}{\begin{tabular}{|l|}
300 \\
IS \\
\end{tabular}} \\
\hline & IS & QS & \\
\hline$\left(\mathrm{Ph}_{4} \mathrm{P}\right) \mathrm{Fe}\left(\mathrm{Et}_{2} \mathrm{dtc}\right)_{3}$ & 1.30 & 2.26 & 1.8 \\
\hline$\left(\mathrm{Bu}_{4} \mathrm{~N}\right) \mathrm{Fe}\left(\mathrm{Et}_{2} \mathrm{dtc}\right)_{3}$ & 1.26 & 3.42 & 1.2 \\
\hline$\left(\mathrm{Et}_{4} \mathrm{~N}\right) \mathrm{Fe}\left(\mathrm{Et}_{2} \mathrm{dtc}\right)_{3}$ & 1.29 & 3.11 & 1.2 \\
\hline$\left[\mathrm{Fe}\left(\mathrm{Et}_{2} \mathrm{dtc}\right)_{2}\right]_{2}+\mathrm{O}_{2} c$ & 0.68 & 1.28 & \\
\hline $\begin{array}{c}{\left[\mathrm{Fe}\left(\mathrm{Et}_{2} \mathrm{dtc}\right)_{2}\right]_{2}+\mathrm{O}_{2}} \\
\text { after recrystn } c\end{array}$ & 0.77 & 0.59 & \\
\hline $\mathrm{Fe}\left(\mathrm{Et}_{2} \mathrm{dtc}\right)_{3}^{-}+\mathrm{O}_{2}(\mathrm{dry})^{c}$ & 0.62 & 0.55 & 0.6 \\
\hline $\mathrm{Fe}\left(\mathrm{Et}_{2} \mathrm{dtc}\right)_{3} d$ & 0.72 & 0.55 & 0.66 \\
\hline
\end{tabular}

$a$ IS is given relative to $\mathrm{Na}_{2} \mathrm{Fe}(\mathrm{CN})_{5} \mathrm{NO} \cdot 2 \mathrm{H}_{2} \mathrm{O}$. ${ }^{b}$ Due $t$ absorption the accuracy of these parameters is equal to 0 $c$ See text. $d$ Reference 5 .

has trigonal symmetry; ${ }^{17}$ assuming a similar distor iron complexes the splitting of the $\mathrm{T}_{2 \mathrm{~g}}$ levels coulc mated from the temperature dependence of the $\mathbf{Q}$ lowing values were derived: $\left(\mathrm{Et}_{4} \mathrm{~N}\right) \mathrm{Fe}\left(\mathrm{Et}_{2} \mathrm{dtc}\right)_{3}, \mathrm{t}$ $\mathrm{cm}^{-1} ;\left(\mathrm{Bu}_{4} \mathrm{~N}\right) \mathrm{Fe}\left(\mathrm{Et}_{2} \mathrm{dtc}\right)_{3}, 800 \pm 100 \mathrm{~cm}^{-1} ;\left(\mathrm{Ph}_{4} \mathrm{P}\right.$ dtc) $)_{3}, 350 \pm 50 \mathrm{~cm}^{-1}$. It should be pointed out t] large QS's and the corresponding $T_{2 g}$ splittings do sarily imply large deviations from octahedral symn 
tion from tetrahedral symmetry that has not been observed in X-ray analysis; in this case the calculated splittings of the $3 \mathrm{~d}$ orbitals are of the same order as found above for (Fe$\left(\mathrm{Et}_{2} \mathrm{dtc}_{3}{ }_{3}{ }^{-18}\right.$ Another example is $\mathrm{Fe}\left(\mathrm{H}_{2} \mathrm{O}\right)_{6} \mathrm{SiF}_{6}$, for which the large QS of $3.7 \mathrm{~mm} / \mathrm{sec}$ is a consequence of an elongation of about $0.04 \AA$ along a trigonal axis of the oxygen octahedron. ${ }^{19}$ The $\mathrm{Fe}\left(\mathrm{Et}_{2} \mathrm{dtc}\right)_{3}{ }^{-}$complexes show very clear electronic spectra in the $4000-13,000 \mathrm{~cm}^{-1}$ range, which are almost independent of the nature of the counterion in the complex. A typical spectrum is shown in Figura 4a. The intensity and width of the bands and the change of the spectrum on oxidation are taken as evidence that these bands correspond to $d-d$ transitions. By using a Du Pont $\mathbf{E} 310$ curve resolver the band positions were determined to be $7100 \pm 400$ and $8300 \pm$ $300 \mathrm{~cm}^{-1}$; the line width is about $2000 \mathrm{~cm}^{-1}$. We assume as in the case of the second $\mathrm{Fe}\left(\mathrm{Me}_{2} \mathrm{dtc}\right)_{2}$ species that these two bands are the two components of the ${ }^{5} \mathrm{E}_{\mathrm{g}} \leftarrow{ }^{5} \mathrm{~T}_{2 \mathrm{~g}}$ transition; the relatively small splitting seems to confirm the high symmetry of the $\mathrm{Fe}\left(\mathrm{Et}_{2} \mathrm{dtc}\right)_{3}{ }^{-}$ion. The $10 D q$ value thus found for the $\mathrm{Et}_{2} \mathrm{dtc}^{-}$ligand is about $7700 \mathrm{~cm}^{-1}$. This value seems to be somewhat low when compared to the $10 D q$ value of about $8800 \mathrm{~cm}^{-1}$ derived for $\mathrm{F}^{-}$from the $\mathrm{d}-\mathrm{d}$ spectrum of $\mathrm{FeF}_{2},{ }^{20} \mathrm{Et}_{2} \mathrm{dtc}^{-}$and $\mathrm{F}^{-}$occupy neighboring positions in the spectrochemical series. However the observed value agrees with the $10 D q$ value derived from the spectrum of the Fe$\left(\mathrm{Me}_{2} \mathrm{dtc}\right)_{2}$ (vide supra). The much larger $10 \mathrm{Dq}$ of $\mathrm{Me}_{2} \mathrm{dtc}^{-}$ as estimated for $\mathrm{Fe}^{\mathrm{III}}\left(\mathrm{Me}_{2} \mathrm{dtc}\right)_{3}$ (about $\left.12,800 \mathrm{~cm}^{-1}\right)^{2}$ is in agreement with the more covalent character of iron(III) compounds as compared to iron(II) compounds. Ir spectra of $\left(\mathrm{R}_{4}^{\prime} \mathrm{N}\right) \mathrm{Fe}\left(\mathrm{Et}_{2} \mathrm{dtc}\right)_{3}$ measured in $\mathrm{KBr}$ disks resemble closely those of $\mathrm{Fe}\left(\mathrm{Et}_{2} \mathrm{dtc}\right)_{3}$. There is possibly a small shift in the frequency of the $\mathrm{C}-\mathrm{N}$ band $\left(\mathrm{Fe}\left(\mathrm{Et}_{2} \mathrm{dtc}\right)_{3}, 1483 \pm 3 \mathrm{~cm}^{-1}\right.$; $\left.\left(\mathrm{R}_{4}^{\prime} \mathrm{N}\right) \mathrm{Fe}\left(\mathrm{Et}_{2} \mathrm{dtc}\right)_{3}, 1478 \pm 3 \mathrm{~cm}^{-1}\right)$, much smaller than the difference observed between $\mathrm{Fe}\left(\mathrm{Et}_{2} \mathrm{dtc}\right)_{3}$ and $\left(\mathrm{BF}_{4}\right) \mathrm{Fe}\left(\mathrm{Et}_{2}\right.$ $\mathrm{dtc})_{3}{ }^{6}$

\section{Summary}

The present results show that tris(dithiocarbamate) complexes of iron(IV) and iron(III) can be extended to iron(II). In general a decrease of the oxidation state of the metal lowers the degree of covalency. In accordance with this the iron(IV) complexes are in the low-spin state, ${ }^{6}$ and the iron(III) complexes may occur in high-spin as well as in lowspin states, ${ }^{2}$ while the experimental data (IS and electronic spectrum) for the iron(II) complex point to a high-spin state. The IS of $\mathrm{Fe}\left(\mathrm{R}_{2} \mathrm{dtc}\right)_{3}{ }^{-}$is smaller than the IS of tris(acetylacetonato)iron(II) where the iron is coordinated by six oxygen atoms (IS $=1.41 \mathrm{~mm} / \mathrm{sec}$ at $\left.100^{\circ} \mathrm{K}\right),{ }^{15}$ which reflects the increase of covalency on going from an iron-oxygen to an

(18) P. R. Edwards, C. E. Johnson, and R. J. P. Williams, J. Chem. Phys., 47, 2074 (1967).

(19) W. C. Hamilton, Acta Crystallogr., 15, 353 (1962).

(20) G. D. Jones, Phys. Rev., 155,259 (1967).

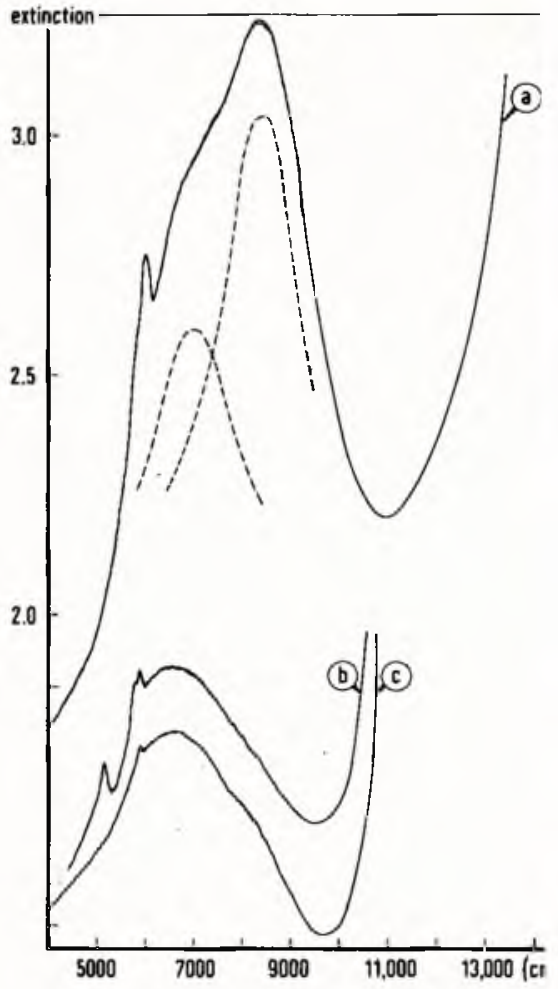

Figure 4. Electronic spectra of (a) $\left(\mathrm{Ph}_{4} \mathrm{P}\right) \mathrm{Fe}\left(\mathrm{Et}_{2} \mathrm{dtc}\right)$ $\mathrm{Fe}\left(\mathrm{Et}_{2} \mathrm{dtc}\right)$, after oxidation in the absence of water, $\left(E t_{2} d t c\right)_{3}$. All spectra were measured on $\mathrm{KBr}$ disks.

iron-sulfur bond. In most high-spin iron(II) $c$ chelates the iron is surrounded by oxygen ator ordination number of 6 . Because of the incre in complexes with sulfur-binding ligands five-c observed in bis(dithiocarbamate) complexes, $n$ iron(II) bis(dimethyldithiocarbamate) both fiv coordination can occur. The $10 D q$ value of $\mathrm{R}$ found to be $8000 \mathrm{~cm}^{-1}$, which is considerably the value for iron(III) complexes, as expected.

Acknowledgment. We wish to thank Dr. J.' suggesting the preparation of the tris(dithiocar plexes and Mr. J. H. M. Gruyters for his coope experiments reported. The assistance of Miss the experimental part of the work is gratefully This investigation was supported in part by the Foundation for Chemical Research (SON) witl aid from the Netherlands Organization for the of Pure Research (ZWO).

Registry No. $\mathrm{Fe}\left(\mathrm{Me}_{2} \mathrm{dtc}\right)_{2}, 41367-62-8 ; \mathrm{Fe}\left(\mathrm{Et}_{2} \mathrm{~d}\right.$ $\mathrm{Fe}\left(n-\mathrm{Pr}_{2} \mathrm{dtc}\right)_{2}, 41367-64-0 ; \mathrm{Fe}\left(n-\mathrm{Bu}_{2} \mathrm{dtc}\right)_{2}, 41429-87$ 41444-80-8; $\mathrm{Fe}[n-\mathrm{Bu}(\mathrm{xn})]_{2}, 41371-75-9 ; \mathrm{Fe}\left(\mathrm{Et}_{2} \mathrm{dsc}_{2}\right.$ $\left(\mathrm{Ph}_{4} \mathrm{P}\right) \mathrm{Fe}\left(\mathrm{Et}_{2} \mathrm{dtc}\right)_{3}, 41371-76-0 ;\left(\mathrm{Bu}_{4} \mathrm{~N}\right) \mathrm{Fe}\left(\mathrm{Et}_{2} \mathrm{dtc}\right)_{3}$, $\left(\mathrm{Et}_{4} \mathrm{~N}\right) \mathrm{Fe}\left(\mathrm{Et}_{2} \mathrm{dtc}_{3}, 41371-78-2\right.$. 